\title{
Pengaruh Ekstrak Etano1 90\% Daun Kelor (Moringa oleifera Lam.) Terhadap Fertilitas Tikus Putih Jantan (Sprague-Dawley)
}

(Effect of ethanol extract 90\% ofMoringa oleifera Lam. leaves on fertility of male white rats (Sprague-Dawley))

\author{
Azrifitria*, Suci Ahda Novitri, Vishilpy Dimalia \& Ratih Dara Syadillah \\ Program Studi Farmasi, Fakultas IImu Kesehatan, Universitas Islam Negeri Syarif Hidayatullah, JI. Ir H. Juanda No.95, \\ Cempaka. Putih, Kec. Ciputat Timur, Kota Tangerang Selatan, Banten 15412
}

\begin{abstract}
Moringa oleifera Lam. is used as traditional medicine and a source of nutrition. Researches on Moringa oleifera Lam. leaves on fertility have been conducted, but variation results are interesting for further research. This study aimed to determine the effect of the ethanol extract $90 \%$ of Moringa oleifera Lam. leaves (EEML) on the fertility using spermatogenesis and aphrodisiac parameters in male white rats (Sprague-Dawley). The male rats were randomly divided into negative group (NaCMC 0.5\%) and test groups $(50,200,800 \mathrm{mg} / \mathrm{kg} \mathrm{BW})$. The EEML was administered orally for 15 days. The results of this study indicated that EEML could increase the serum testosterone level. Although not significant $(p>0.05)$, the increase was still in normal concentrations (0.66$0.54 \mu \mathrm{g} / \mathrm{ml}$ ). Spermatozoa concentration increased significantly $(p<0.05)$ at a dose of $800 \mathrm{mg} / \mathrm{kgBW}$. However, the seminiferous tubule diameter and testicular weight did not significantly increase ( $p>0.05)$ at all doses of the test groups. The EEML did not affect the mounting frequency and latency, intromission latency, as well as the frequency of male rats significantly ( $p>0.05)$. Based on these results, it can be concluded that EEML has the potential to increase the effect of spermatogenesis compared to the aphrodisiac effect on male rats in 15 days.
\end{abstract}

Keywords: spermatogenesis; aphrodisiac; Moringa oleifera Lam.; testosterone; fertility.

ABSTRAK: Kelor (Moringa oleifera Lam.) banyak digunakan sebagai obat tradisional dan sumber nutrisi yang baik. Penelitian daun kelor tentang fertilitas telah pernah dilakukan, namun adanya perbedaan hasil menjadi hal yang menarik untuk diteliti lebih lanjut. Penelitian ini bertujuan untuk mengetahui efek ekstrak etanol $90 \%$ daun kelor (EEDK) terhadap fertilitas dengan parameter spermatogenesis dan afrodisiak pada tikus putih jantan (Sprague-Dawley). Tikus putih jantan dibagi secara acak menjadi kelompok normal (NaCMC 0,5\%), kelompok uji (EEDK dosis 50, 200 dan 800 mg/kgBB). Pemberian EEDK diberikan secara oral selama 15 hari. Hasil penelitian ini menunjukkan bahwa EEDK dapat meningkatkan serum testosteron namun tidak bermakna $(p>0,05)$, masih dalam konsentrasi normal $(0,66-0,54 \mu \mathrm{g} / \mathrm{ml})$. Konsentrasi spermatozoa meningkat secara bermakna $(p<0,05)$ pada dosis $800 \mathrm{mg} /$ $\mathrm{kgBB}$, namun diameter tubulus seminiferus dan bobot testis tidak berbeda bermakna $(p>0,05)$ pada semua dosis kelompok uji. Pemberian EEDK tidak mempengaruhi efek mounting frequency dan latency serta intromission latency dan frequency pada tikus jantan secara bermakna $(p>0,05)$. Berdasarkan hasil tersebut, dapat disimpulkan bahwa pemberian EEDK pada tikus putih jantan (Sprague-Dawley) selama 15 hari memiliki potensi terhadap efek spermatogenesis dibandingkan dengan efek afrodisiak.

Kata kunci: spermatogenesis; afrodisiak; Moringa oleifera Lam.; testosteron; fertilitas.

\section{Pendahuluan}

Kelor (Moringa oleifera Lam.) merupakan salah satu tumbuhan yang memiliki banyak khasiat dan memiliki kandungan nutrisi yang baik. Tumbuhan kelor telah digunakan sebagai obat seperti anemia, asma, penyembuh luka, diabetes melitus, hiperlipidemia, dan lain-lain [1]. Masyarakat memilih obat dari tanaman atau tumbuhan sebagai pengobatan alternatif dengan biaya yang lebih murah dan diyakini lebih aman dibanding obat sintetik [2]. Penggunaan obat tradisional sebagai salah satu pengobatan Complementary and Alternative Medicine (CAM) akan terus mengalami peningkatan. Menurut WHO ( World Health Organization), sebanyak $80 \%$ penduduk dibenua Asia dan Afrika bergantung pada pengobatan tradisional [3]. Berdasarkan data Riset Kesehatan Dasar (Riskesdas) tahun 2018 menunjukkan bahwa 31,4\% masyarakat Indonesia telah memanfaatkan pelayanan kesehatan tradisional, diantaranya $48 \%$ memanfaatkan ramuan jadi, 31,8\% memanfaatkan ramuan buatan sendiri. Salah satu obat tradisional yang banyak digunakan oleh masyarakat adalah

\section{Article history}

Received: 28 Mei 2021 Accepted: 30 Okt 2021 Published: 07 Des 2021

Access this article

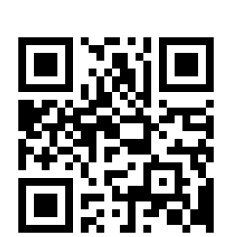


daun kelor [4].

Kelor kaya dengan kandungan protein, vitamin A, mineral, asam amino essensial, antioksidan dan flavonoid serta isothiocyanates [5]. Daun kelor memiliki kandungan nutrisi seperti vitamin A, vitamin C, asam amino, kalsium, kalium, magnesium, protein dan polifenol [6], vitamin $\mathrm{B}$, vitamin E, riboflavin, asam nikotinat, asam folat, piridoksin, mineral dan berbagai senyawa fenolik [7]. Kandungan fitokimia daun kelor yang telah dilaporkan adalah niazirin dan niazirinin-glikosida nitril, phenolic acidsgallic, asam klorogenik, ellagic acid and ferulic acid, flavonoidskaempferol, kuersetin, rutin dan lain-lain [8]. Di India, biji kelor secara tradisional untuk meningkatkan gairah seksual (afrodisiak) [9]. Berdasarkan hasil penelitian yang dilaporkan oleh Cajuday (2010), pemberian ekstrak heksana daun kelor pada dosis 0,5, 5 dan $50 \mathrm{mg} / 30 \mathrm{~g}$ selama 21 hari dapat mempengaruhi sistem reproduksi yang meliputi peningkatan pada bobot testis, epididimis, vesikula seminalis, diameter tubulus seminiferus pada mencit jantan [10]. Pemberian ekstrak air daun kelor pada dosis 200 dan $400 \mathrm{mg} / \mathrm{kgBB}$ selama 21 hari dapat meningkatkan kadar testosteron, sperma dan dapat memperbaiki struktur histologi jaringan testis pada kelinci jantan [11]. Namun pada penelitian lain, dilaporkan bahwa pemberian ekstrak etanol daun kelor $(200 \mathrm{mg} / \mathrm{kgBB})$ pada tikus jantan selama 28 hari memberikan efek antifertilitas karena menunjukkan kerusakan sel germinal pada tubulus seminiferus [12].

Berdasarkan hasil penelitian tersebut, adanya perbedaan efek daun kelor terhadap fertilitas tikus jantan sehingga menjadi hal yang menarik untuk diteliti lebih lanjut. Dari penelitian sebelumnya, belum ada uji ekstrak etanol 90\% daun kelor (EEDK) dengan variasi dosis 50, 200 dan $800 \mathrm{mg} / \mathrm{KgBB}$ pada tikus jantan terhadap parameter spermatogenesis dan afrodisiak secara menyeluruh. Tujuan dari penelitian adalah mengetahui efek ekstrak etanol 90\% daun kelor dengan variasi dosis 50, 200 dan $800 \mathrm{mg} / \mathrm{kgBB}$ terhadap fertilitas dengan parameter spermatogenesis dan afrodisiak pada tikus jantan galur (Sprague-Dawley) secara in vivo. Efek spermatogenesis dari EEDK dilakukan dengan mengukur parameter konsentrasi testosteron, spermatozoa, diameter tubulus seminiferus dan bobot testis, sedangkan efek afrodisiak dengan mengamati mounting dan intromission. Penelitian ini akan memberikan gambaran potensi yang lebih menyeluruh terhadap aspek fertilitas EEDK yang belum pernah diteliti sebelumnya.

\section{Metode Penelitian}

Bahan

Daun kelor (Kampung Tegalwaru, Bogor, Indonesia), etanol 90\% (Bratachem, Indonesia), tikus putih jantan galur Sprague-Dawley, Na CMC 0,25\% (Aloin Labora, Indonesia), kit ELISA testosterone (DRG International, USA).

\section{Penyiapan Ekstrak}

Daun kelor dicuci bersih, dikering-anginkan pada suhu ruang dan terhindar dari sinar matahari langsung, kemudian dihaluskan dengan cara diblender (Philips ${ }^{\mathbb{R}}$, Indonesia). Sampel dimaserasi dengan pelarut etanol 90\% selama 24 jam kemudian disaring sehingga mendapatkan maseratnya. Maserat yang diperoleh diuapkan dengan menggunakan rotary evaporator (EYEL $A^{\circledR}$, USA), subu 40- $43^{\circ} \mathrm{C}$ sehingga mendapatkan ekstrak kental kemudian dilakukan freeze dry.

\section{Karakterisasi Ekstrak}

Karakterisasi yang dilakukan terhadap ekstrak uji adalah uji organoleptik, penetapan kadar abu dan kadar air [13]. Ekstrak etanol 90\% daun kelor (EEDK) juga diuji kandungan senyawa metabolit sekunder flavonoid, terpenoid/steroid, alkaloid, fenol, saponin, tannin dan fitosterol [13].

\section{Penyiapan Hewan}

Hewan uji yang digunakan pada penelitian ini telah lolos Kaji Etik Fakultas Kedokteran Universitas Indonesia dengan Nomor: 565/UN2.F1/ETIK/2017. Hewan uji diaklimatisasi selama 7 hari sebelum dilakukan pengujian. Hewan uji digunakan sebanyak 20 ekor yang dibagi menjadi 4 kelompok yaitu kontrol normal (NaCMC 0,25\%) dan 3 kelompok uji (EEDK dosis 50, 200, $800 \mathrm{mg} / \mathrm{kgBB}$ ) untuk pengukuran parameter konsentrasi testosteron, konsentrasi spermatozoa, diameter tubulus seminiferus, bobot testis, mounting frequency dan latency serta intromission frequency dan latency.

\section{Parameter Spermatogenesis}

\section{Pengukuran Konsentrasi Testosteron}

Hewan uji diberi EEDK selama 15 hari. Darah diambil sebanyak $2 \mathrm{ml}$ melalui sinus orbitalis mata pada hari ke-0 dan hari ke-16, kemudian pisahkan serum dengan cara sentrifugasi menggunakan kecepatan 3000rpm selama 15 menit, diukur konsentrasinya [9]. Pengukuran konsentrasi testosteron dilakukan dengan menggunakan metode Ensyme Linked Immunosorbent Assay (ELISA). 


\section{Pengukuran Konsentrasi Spermatozoa}

Kauda epididimis diambil untuk dihitung spermatozoanya. Sampel diletakkan ke dalam cawan petri yang berisi cairan $\mathrm{NaCl}$ 0,9\% sebanyak $500 \mu$ l, kemudian dimasukkan ke dalam kamar Hemasitometer-Neubauer (Nesco, China) hingga kamar hitung terisi rata. Jumlah sperma dihitung pada salah satu kamar HemasitometerNeubauer, kemudian ditentukan faktor pengenceran dan dihitung jumlah kotak kecil Neubauer yang diisi oleh spermatozoa. Lakukan perhitungan konsentrasi spermatozoa dengan rumus [14]:

Jumlah sperma x 10.000 x faktor pengenceran (25/ Jumlah kotak kecil Neubauer) x volume $\mathrm{NaCl}$.

\section{Diameter Tubulus Seminiferus}

Preparat histologi testis dibuat dan dilihat dibawah mikroskop (Motic, Jerman) perbesaran 100x dengan mengukur jarak antara dua titik yang berseberangan pada garis tengahnya yang terpendek, dan mengukur jarak terjauh antara titik yang berseberangan, lalu dibagi dua. Tubulus yang diukur adalah yang memiliki penampang bulat (ukuran yang kurang lebih sama). Tiap masingmasing preparat diukur minimal 10 tubulus dengan hasil pengukuran dinyatakan dalam satuan mikrometer $(\mu \mathrm{m})$ $[15,16]$.

\section{Bobot testis}

Tikus dikorbankan pada hari ke-16, kemudian keluarkan testis dari skrotumnya dan ditimbang. Bobot testis perlakuan dibandingkan dengan bobot testis kontrol, kemudian hasilnya dibandingkan dengan bobot badan tikus setelah perlakuan dikali $100 \%$ untuk mendapatkan $\%$ proporsi bobot testis.

\section{Mounting dan Intromission}

Pada hari ke-15, pukul 20.00 WIB, tikus jantan dan tikus betina estrus dipertemukan dalam satu kandang (pencahayaan rendah) dengan perbandingan 1:1. Pengamatan mounting latency, mounting frequency, intromission latency dan intromission frequency dilakukan selama 30 menit. Pencatatan dilakukan terhadap mounting latency (waktu dari mulai perkenalan tikus betina ke dalam kandang hingga tunggangan pertama), mounting frequency (jumlah tunggangan tikus jantan ke betina sebelum ejakulasi), intromission latency (interval waktu dari perkenalan pada hewan betina sampai intromisi pertama oleh hewan jantan) dan intromission frequency (jumlah intromisi dari waktu perkenalan pada hewan betina sampai ejakulasi) [17].

\section{Analisis Data}

Seluruh data diolah secara statistik (uji normalitas, homogenitas, parametrik atau non parametrik) dengan menggunakan software SPSS 20. Uji multiple comparison tipe LSD (Least Significant Different) akan dilakukan jika hasil uji parametrik dan non parametrik menunjukkan hasil yang bermakna $(p<0,05)$.

\section{Hasil dan Diskusi}

Ekstrak etanol 90\% daun kelor (EEDK) berbentuk ekstrak kental, warna coklat, berbau khas dan berasa pahit. Kadar air EEDK sebesar 12,04\% dan kadar abu sebesar 8,39\%. Skrining fitokimia menunjukkan bahwa EEDK mengandung senyawa flavonoid, alkaloid, saponin, tanin, steroid dan terpenoid. Hasil ini didukung oleh penelitian sebelumnya yang menunjukkan bahwa ekstrak etanol daun kelor memiliki kandungan fitokimia alkaloid, flavonoid, saponin, tanin [18].

Pada penelitian ini, pengukuran konsentrasi testosteron pada hari ke-0 dan ke-16 menunjukkan adanya perubahan konsentrasi testosteron namun masih rentang normal

Tabel 1. Hasil pemberian EEDK selama 15 hari pada tikus putih jantan

\begin{tabular}{|c|c|c|c|c|c|}
\hline \multirow[t]{2}{*}{ Kelompok Perlakuan } & \multicolumn{2}{|c|}{$\begin{array}{c}\text { Kadar Serum Testosteron } \\
(\mathrm{ng} / \mathrm{ml}) \pm \mathrm{SD}\end{array}$} & \multirow{2}{*}{$\begin{array}{l}\text { Rerata Konsentrasi } \\
\text { Spermatozoa } \\
\text { (juta/mL) } \pm \text { SD }\end{array}$} & \multirow{2}{*}{$\begin{array}{c}\text { Rerata Diameter } \\
\text { Tubulus Seminiferus } \\
(\mu \mathrm{m}) \pm S D\end{array}$} & \multirow{2}{*}{$\begin{array}{c}\text { Proporsi Bobot Testis } \\
(\%) \pm S D\end{array}$} \\
\hline & $\mathrm{H}-\mathrm{O}$ & H-16 & & & \\
\hline Kontrol & $2.24 \pm 0.82$ & $2.12 \pm 1.05$ & $13,87 \pm 2,55$ & $203,16 \pm 9,90$ & $0.41 \pm 0.03$ \\
\hline 50 mg/kgBB & $1.45 \pm 0.88$ & $2.40 \pm 1.01$ & $17,12 \pm 5,12$ & $206,16 \pm 12,70$ & $0.42 \pm 0.04$ \\
\hline $800 \mathrm{mg} / \mathrm{kgBB}$ & $1.25 \pm 0.61$ & $2.00 \pm 1.38$ & $28,00 \pm 10,21^{*}$ & $198,81 \pm 9,80$ & $0.43 \pm 0.04$ \\
\hline
\end{tabular}

Keterangan: $\mathrm{n}=5$; $\mathrm{SD}=$ Standar Deviasi; $*=$ perbedaan signifikan terhadap kelompok kontrol $(\mathrm{p}<0,05)$ 
$(0,66$ - 5,4 ng/ml) dan tidak berbeda bermakna (tabel 1.). Hasil ini didukung oleh penelitian sebelumnya yaitu pemberian EEDK $500 \mathrm{mg} / \mathrm{kgBB}$ pada tikus selama 56 hari menunjukkan perubahan konsentrasi testosteron tidak berbeda bermakna terhadap kelompok kontrol normal [19].

Testosteron merupakan hormon steroid yang berperan terhadap spermatogenesis dan afrodisiak [20]. Testosteron disintesis pada sel Leydig dalam testis yang distimulasi oleh LH yang disekresi dari hipofisis interior dan dipengaruhi oleh GnRH dari hipotalamus [21]. Pemberian EEDK dapat meningkatkan stimulasi sintesis testosteron, terlihat pada peningkatan konsentrasi sesudah pemberian EEDK dibandingkan dengan sebelum pemberian EEDK. Testosteron akan berdifusi ke dalam tubulus seminiferus dan menginduksi spermatogenesis [22].

Spermatozoa dihasilkan dari beberapa lapisan sel-sel spermatogenik yang membelah dan berdiferensiasi di dalam tubulus seminiferus. Perhitungan konsentrasi spermatozoa sering digunakan untuk mengukur produksi sperma, fungsi testis dan fertilitas pada pria [23]. Hasil pemberian EEDK selama 15 hari menunjukkan peningkatan konsentrasi spermatozoa secara bermakna $(\mathrm{p}<0,05)$ hanya pada dosis tinggi $(800 \mathrm{mg} / \mathrm{kgBB})$ terhadap kelompok kontrol (tabel 1.). Peningkatan konsentrasi spermatozoa di penelitian ini pada dosis yang tinggi diduga karena pengaruh jumlah kandungan senyawa yang memiliki aktivitas antioksidan yang ada didalam ekstrak etanol 90\% daun kelor yaitu flavonoid, vitamin C, karotenoid, fenolik, klorofil. Flavonoid diketahui memiliki aktivitas antioksidan kuat yang dapat memperbaiki kerusakan testis akibat stress oksidatif pada jaringan hewan, merangsang androgenesis testis [9] dan mampu menstimulasi aktivitas sel Sertoli dan sel Leydig pada tubulus seminiferus, sehingga meningkatkan konsentrasi spermatozoa [24].

Pengukuran diameter tubulus seminiferus dapat digunakan untuk menggambarkan produksi spermatozoa dan salah satu cara untuk melihat ada tidaknya gangguan proses spermatogenesis [25]. Hasil pengukuran diameter tubulus seminiferus pada kelompok uji selama 15 hari pada penelitian ini menunjukkan bahwa tidak adanya perubahan secara bermakna $(p>0,05)$ terhadap kelompok kontrol normal (tabel 1.). Hal ini sesuai dengan data konsentrasi spermatozoa yang tidak meningkat secara bermakna kecuali pada dosis tinggi $(800 \mathrm{mg} / \mathrm{kgBB})$. Belum linearnya peningkatan diameter tubulus seminiferus dengan konsentrasi spermatozoa pada dosis $800 \mathrm{mg} / \mathrm{kgBB}$ diduga karena belum optimalnya siklus spermatogenesis pada penelitian ini, dimana siklus spermatogenesis pada tikus jantan adalah 54 hari [26].

Pada penelitian lain dengan menggunakan ekstrak heksan daun kelor $(0,5,5,50 \mathrm{mg} / 30 \mathrm{gBB})$ pada mencit jantan selama 21 hari mampu meningkatkan diameter tubulus seminiferus secara bermakna [10]. Hal ini diduga karena perbedaan kepolaran pelarut pada ekstrak uji yang menyebabkan perbedaan kandungan zat aktif dan efek yang dihasilkan. Penelitian lain menyebutkan bahwa kandungan total flavonoid pada ekstrak heksan daun kelor lebih besar dibandingkan dengan ekstrak etanol [27].

Parameter spermatogenesis yang lain adalah bobot testis, karena jumlah tubulus dan bagian sel germinal diperkirakan memenuhi $98 \%$ dari masa testis [28]. Perbandingan pengukuran rerata proporsi bobot testis kelompok EEDK menunjukkan adanya peningkatan secara tidak bermakna $(p>0,05)$ terhadap kelompok kontrol (tabel 2.). Penelitian ini menunjukkan bahwa pemberian EEDK tidak mempengaruhi bobot testis hewan uji. Hasil ini mendukung data diameter tubulus seminiferus yang tidak ada perubahan secara bermakna ( $>0,05)$ terhadap kelompok kontrol. Hal ini diduga karena lamanya perlakuan yang dilakukan selama 15 hari yang belum meningkatkan bobot testis dan tubulus

Tabel 2. Hasil pengamatan mounting dan intromission setelah pemberian EEDK selama 15 hari pada tikus jantan

\begin{tabular}{|c|c|c|c|c|c|c|c|c|}
\hline \multirow{2}{*}{$\begin{array}{l}\text { Kelompok } \\
\text { Perlakuan }\end{array}$} & \multicolumn{3}{|c|}{ Mounting } & \multicolumn{5}{|c|}{ Intromission } \\
\hline & $\begin{array}{l}\text { Frequency } \\
\text { (kali) } \pm \text { SD }\end{array}$ & $\begin{array}{c}\text { Latency } \\
\text { (detik) } \pm S D\end{array}$ & $\mathbf{N}$ & $\mathbf{n}$ & $\begin{array}{c}\text { Frequency } \\
\text { (kali) } \pm S D\end{array}$ & $\begin{array}{c}\text { Latency } \\
\text { (detik) } \pm S D\end{array}$ & $\mathbf{N}$ & n \\
\hline Kontrol Normal & $2,8 \pm 2,59$ & $570,2 \pm 452,21$ & 5 & 4 & $0,2 \pm 0,45$ & $288 \pm 643,99$ & 5 & 1 \\
\hline $50 \mathrm{mg} / \mathrm{kgBB}$ & $3,6 \pm 8,05$ & $25,4 \pm 56,80$ & 5 & 1 & $2,8 \pm 6,26$ & $70,4 \pm 157,42$ & 5 & 1 \\
\hline $200 \mathrm{mg} / \mathrm{kgBB}$ & $0,2 \pm 0,45$ & $239 \pm 534,42$ & 5 & 1 & 0 & 0 & 5 & 0 \\
\hline $800 \mathrm{mg} / \mathrm{kgBB}$ & $1 \pm 2,23$ & $29,6 \pm 66,19$ & 5 & 1 & 0 & 0 & 5 & 0 \\
\hline
\end{tabular}

Keterangan: $\mathrm{N}=$ jumlah tikus perlakuan; $\mathrm{n}=$ jumlah tikus yang melakukan mounting atau intromission 
seminiferus secara optimal. Pemberian EEDK selama 15 hari tidak mempengaruhi parameter afrodisiak pada tikus jantan dengan pengamatan mounting latency, mounting frequency, intromission latency dan intromission frequency yang tidak berbeda bermakna $(p>0,05)$ terhadap kelompok normal (tabel 2.). Pada penelitian lain menunjukkan bahwa ekstrak etanol biji kelor dapat meningkatkan efek afrodisiak secara bermakna $(\mathrm{p}<0,05)$. Hal ini dapat kita lihat bahwa efek afrodisiak pada biji kelor lebih berpotensi dibanding dengan daun kelor, diduga karena perbedaan kandungan saponin dan steroid. Kandungan saponin dan steroid berpotensi memiliki efek afrodisiak yang dapat digunakan dalam pengobatan impotensi [29].

Berdasarkan uraian hasil pengujian parameter spermatogenesis dan afrodisiak dapat disimpulkan bahwa pemberian EEDK selama 15 hari pada tikus jantan mempengaruhi parameter spermatogenesis pada dosis 800 $\mathrm{mg} / \mathrm{kgBB}$ yang meningkatkan konsentrasi spermatozoa secara bermakna $(p<0,05)$, namun tidak mempengaruhi parameter afrodisiak pada tikus jantan $(\mathrm{p}>0,05)$. Perlunya penelitian lebih lanjut terkait optimasi lama pemberian dan pengamatan histopatologi spermatogenesis di tubulus seminiferus.

\section{Kesimpulan}

Pemberian ekstrak etanol 90\% daun kelor (EEDK) pada tikus jantan selama 15 hari mempengaruhi parameter spermatogenesis pada dosis $800 \mathrm{mg} / \mathrm{kgBB}$ yang meningkatkan konsentrasi spermatozoa secara bermakna $(p<0,05)$. Pemberian EEDK tidak mempengaruhi parameter afrodisiak pada tikus jantan ( $>>0.05)$. Konsentrasi hormon testosteron mengalami peningkatan sesudah perlakuan, namun tidak berbeda bermakna $(p>0,05)$. EEDK memiliki potensi terhadap efek spermatogenesis dibandingkan dengan efek afrodisiak.

\section{Referensi}

[1]. BPOM. Kekuatan Budaya Nusantara untuk Kesehatan Dunia "Kelor Moringa oleifera Lam. In Jakarta: Direktorat Obat Asli Indonesia BPOM; 2016

[2]. Permenkes RI. Peraturan Menteri Kesehatan Republik Indonesia Nomor 88 Tahun 2013 Tentang Rencana Induk Pengembanagan Bahan Baku Obat Tradisional. Jakarta; 2013.

[3]. Yuningsih R. Pengobatan tradisional di unit pelayanan kesehatan. Info Singk Kesejaht Sos. 2012;4(05):36-9.

[4]. Riskesdas K. Hasil Utama Riset Kesehata Dasar (RISKESDAS) 2018. Kementerian Kesehatan RI. 2018;1-220. https://doi. org/10.1088/1751-8113/44/8/085201

[5]. Kou X, Li B, Olayanju JB, Drake JM, Chen N. Nutraceutical or pharmacological potential of Moringa oleifera Lam. Nutrients. 2018;10(3). https://doi.org/10.3390/nu10030343
[6]. Ganatra Tejas H, Joshi Umang H, Bhalodia Payal N, Desai Tusharbindu R, Tirgar Pravin R. A Panoramic View on Pharmacognostic, Pharmacological, Nutritional, Therapeutic and Prophylactic Values of Moringa Oleifera Lam. Int Res J Pharm. 2012;3(6):1-7.

[7]. Adaora V, Florett C. Nutritional, Therapeutic, and Prophylactic Properties of Vigna subterranea and Moringa oleifera. AntioxidantAntidiabetic Agents Hum Heal. 2014; https://doi.org/10.5772/57338

[8]. Priyatama V. Moringa Oleifera: Panaromic View on Nutritional, Therapeutic Activity and Patent Landscape. Int J Pharm Sci Dev Res. 2018;3(1):024-8. https://doi.org/10.17352/ijpsdr.000012

[9]. Dafaalla MM, Abass S, Abdoun S, Hassan AW, Idris OF. Effect of ethanol extract of Moringa oleifera leaves on fertility hormone and sperm quality of male Albino Rats. Int J Multidiscip Res Dev. 2015;5(1):01-11. Available from: www.allsubjectjournal.com

[10]. Cajuday LA, Pocsidio GL. Effects of Moringa oleifera Lam. (Moringaceae) on the reproduction of male mice (Mus musculus). J Med Plants Res. 2010;4(12):1115-21. https://doi.org/10.5897/ JMPR09.200

[11]. Khalifa WH, Ibrahim FM, El Al, Sharaf HA, Wagdy KB, Maghraby NA. Safety and Fertility Enhancing Role of Moringa Oleifera Leaves. Int J Pharm. 2016;6(1):156-68.

[12]. Owolabi, J O OP. Histological evaluation of the effects of Moringa leaf extract treatment on vital organs of murine models. Merit Res J Med Med Sci. 2014;2(10):245-57. Available from: http://www. meritresearchjournals.org/er/index.htm

[13]. Departemen Kesehatan RI DKR. Parameter Standarisasi Umum Ekstrak Tumbuhan Obat. Jakarta: Direktorat Jenderal Pengawasan Obat dan Makanan; 2000.

[14]. Susilo S, Akbar B, Pratinaningsih I. Pengaruh Ekstrak Etanol Daun Sambiloto Terhadap Jumlah Dan Motilitas Spermatozoa Mencit Jantan. J Biodjati. 2018;3(2):68-74. https://doi.org/10.15575/ biodjati.v3i2.3505

[15]. Türk G, Sönmez M, Aydin M, Yüce A, Gür S, Yüksel M, et al. Effects of pomegranate juice consumption on sperm quality, spermatogenic cell density, antioxidant activity and testosterone level in male rats. Clin Nutr. 2008;27(2):289-96. https://doi.org/10.1016/j. clnu.2007.12.006

[16]. Amaliah AM, Sutyarso, Rahmanisa S. Bisphenol-a (BPA) Menurunkan Diameter Tubulus Seminiferus Tikus Putih Jantan ( Rattus norvegicus ) Galur Spraque dawley. Agromedicine. 2019;6(2):270-6.

[17]. Deshmukh CKSKB. Butea monosperma (Lam.) Induces Sexual Activity in Male Albino Rat, Rattus rattus (Wistar). Int J Phys Appl Sci (Impact Factor-3960). 2016;03(04):2016

[18]. Nurulita NA, Sundhani E, Amalia I, Rahmawati F, Nurhayati N, Utami D. Uji Aktivitas Antioksidan dan Anti-aging Body Butter dengan Bahan Aktif Ekstrak Daun Kelor ( Antioxidant and Anti-aging activity of Moringa Leaves Extract Body Butter ). J Ilmu Kefarmasian Indones. 2019;17(1):1-8

[19]. Elblehi SS, El Euony OI, El-Nahas AF. Partial ameliorative effect of Moringa leaf ethanolic extract on the reproductive toxicity and the expression of steroidogenic genes induced by subchronic cadmium in male rats. Environ Sci Pollut Res. 2019;26(23):23306-18. https:// doi.org/10.1007/s11356-019-05607-y

[20]. Sukmaningsih AASA, Gunam IBW, Antara NS, Kencana PKD, Widia IW. Rebung Bambu Tabah (Gigantochloa Nigrociliata) Berpotensi Sebagai Bahan Afrodisiak pada Mencit Jantan (POTENTIAL APHRODISIAC ACTIVITY OF TABAH BAMBOO SHOOTS (GIGANTOCHLOA NIGROCILIATA) IN MALE MOUSE). J Vet. 2017;18(3):393. https://doi. org/10.19087/iveteriner.2017.18.3.393

[21]. Hasbi H, Gustina S. Androgen Regulation in Spermatogenesis to Increase Male Fertility. Indones Bull Anim Vet Sci. 2018;28(1):13. https://doi.org/10.14334/wartazoa.v28i1.1643

[22]. Muharram, Adnan, Faqih A, Jihadi A. UJI DAYA KONSEPSI EKSTRAK METANOL DAUN TAPAK DARA (Catharantus roseus) TERHADAP MENCIT (Mus musculus) ICR JANTAN. Indones J Fundam Sci. 2018;4(2):102-9. https://doi.org/10.26858/ijfs.v5i1

[23]. Dorostghoal M, Seyyednejad SM, Khajehpour L, Jabari A. Effects of Fumaria parviflora leaves extract on reproductive parameters in 
adult male rats. Iran J Reprod Med. 2013:11(11):891-8.

[24]. Lembe D, Koloko B, Bend E, Domkam J, Oundoum P, Njila M, et al. Fertility enhancing effects of aqueous extract of Rauvolfia vomitoria on reproductive functions of male rats. J Exp Integr Med. 2014;4(1):43. https://doi.org/10.5455/ieim.200913.or.090

[25]. Brown JL, Bush M, Packer C, Janssen D, Reiziss SM, Wildt DE. Panthera leo ) of the Serengeti Plains and Ngorongoro Crater of. J Reprod Fertil. 1996

[26]. Perrard MH, Sereni N, Schluth-Bolard C, Blondet A, Giscard d'Estaing $\mathrm{S}$, Plotton I, et al. Complete human and rat ex vivo spermatogenesis from fresh or frozen testicular tissue. Biol Reprod. 2016;95(4):1-10. https://doi.org/10.1095/biolreprod.116.142802

[27]. Abo El-Fadl S, Osman A, Al-Zohairy A, Dahab A, Abo El Kheir Z. Assessment of Total Phenolic, Flavonoid Content, Antioxidant Potential and Hplc Profile of Three Moringa Species Leaf Extracts. Sci J Flowers Ornam Plants. 2020;7(1):53-70. https://doi.org/10.21608/ sjfop.2020.91397

[28]. Izunya AM, Nwaopara AO, Aigbiremolen A, Oaikhena GA. Body and testicular weight changes in adult wistar rats following oral administration of artesunate. Res J Appl Sci Eng Technol. 2010;2(3):302-6

[29]. Zade V, Dabhadkar D, Thakare V, Pare S. Evaluation of Potential Aphrodisiac Activity of Moringa Oleifera Seed in Male Albino Rats. Int J Pharm Pharm Sci. 2013;5(4)

Copyright @ 2021 The author(s). You are free to share (copy and redistribute the material in any medium or format) and adapt (remix, transform, and build upon the material for any purpose, even commercially) under the following terms: Attribution - You must give appropriate credit, provide a link to the license, and indicate changes were made. You may do so in any reasonable manner, but not in any way that suggests the licensor endorses you or your use; ShareAlike - If you remix 